\title{
Quality of Sausage Prepared with Grape seeds as Natural Antioxidants
}

\author{
Reham El-Badrawy. A. Zahran
}

\begin{abstract}
Effect of different levels (200, 400 and $600 \mathrm{mg} / \mathrm{kg}$ ) of grape seeds (GS) as powder on chemical, physical, and organoleptic properties of fresh, cooked sausages and during frozen storage at $-18 \mathrm{oC}$ for 3 months were examined. The results showed that with progress of storage period up to 3 months, the moisture and protein content decreased, while fat, ash, fiber, carbohydrates and energy value, increased. Sausage with $600 \mathrm{mg} / \mathrm{kg}$ grape seeds recorded the lowest T.B.A value. Also, addition of grape seeds to sausages enhancement of all tested physical properties and organoleptic evaluation by different rates. As conclusion, addition of grape seeds to sausages delay fat rancidity and improvement sausages quality.
\end{abstract}

Keywords: By-products, Grape seeds, Meat product, Antioxidants and TBA

\section{INTRODUCTION}

In the food processing industry, edible portions of fruits are processed into products such as puree, canned slices, juice and pickles, whereas seeds often will be discarded as waste since it is not currently utilized for commercial purposes, seeds are also promising source of useful compounds because of their favorable technological or nutritional properties (Ajila et al., 2007).

The grape (Vitis vinifera, L.), which has a long history of cultivation and utilization, is one of the most important commercial fruit crops worldwide. There are more than 70 grape species and a large number of grape cultivars growing all over the world (Uzun, 2010).

Grapes are one of the largest fruit crops in the world. Grapes are used for wine production, leaving about 10 million tons of waste annually, after the juice is extracted as reported by Kammerer et al., (2004). 
Many studies have shown that grapes are used for medical purposes, animal feed, cosmetics, and to increasing shelf life for meat and meat products (Kulkarni et al., 2011).

Nawaz et al., (2006) have reported that polyphenol compounds have various classes which ranged from phenolic acids, colored anthocyanins, simple flavonoid and complex flavonoids. Flavonoids are as the most abundant and potent group of plant phenolic compounds which act as antioxidants.

The antioxidant activity of grape seeds extract (GSE) has been reported to improve the oxidative stability in a variety of food systems including cooked beef, turkey and pork patties, and cold stored turkey meat (Baydar et al., 2006).

Antioxidants are one of the additives which have attracted more attention in last decades. A vast number of plants, food and food wastes have been screened for potential antioxidant activity. Most studies have been focused on the identification of bioactive components, with special emphasis on those of phenolic nature (Conde et al., 2013).

An interest in natural antioxidants, especially of vegetal origin, has greatly increased in recent years. Natural antioxidants can protect the human body from free radicals that may lead to the aging process and cause some chronic diseases including cancer, cardiovascular diseases and cataract as well as retard lipid oxidative rancidity in foods (Lai et al., 2001).

Antioxidants are agents which scavenge the free radicals and prevent the damage caused by them. They can greatly reduce the damage by neutralizing the free radicals before they can attack the cells and prevent damage to lipids, proteins, enzymes, carbohydrates and DNA (Lee et al., 2004).

The lipid oxidation is one of the major problems in meat industries. Meat products that are constituted of lipid and polyunsaturated fatty acids (PUFAs) tend to deteriorate due to lipid oxidation, leading to development of unpleasant flavors during processing and storage. The adverse effect of lipid 
oxidation leads to the development of free radicals which are involved in diseases and a range of disorders including cancer, arthritis, atherosclerosis, Alzheimer's disease, and diabetes. The supplement of synthetic antioxidants is a method of inhibiting lipid oxidation in meat products. However, synthetic antioxidants such as butylatedhydoxyanisole (BHA) and butylatedhydroxytolune (BHT) have restricted use in foods as these agents are known to be carcinogenic (Baydar et al., 2007).

Rather et al., (2018) reported that oxidation is a key problem that reduces the shelf life of fresh and processed meat and meat products. Antioxidants are added to stabilize free radicals there by delaying lipid and protein oxidation, retard development of off-flavors, and improve colour stability. Addition of synthetic antioxidants to combat oxidative damage has the potential to cause adverse health effects and thus remained a challenge to the meat industry.

Meat is a highly nutritious food rich in high biological value proteins, fatty acids, vitamins ( $B$ and $E$ ), minerals and bioactive compounds (conjugated linoleic acid, L-carnitin, carnosine, etc.). The processing of meat into products represents one of the most economically significant food industries around the world because of the new consumer's preference for ready-toeat-foods (Mehta et al., 2015).

Sausages such as Frankfurt, Bologna and mainly Viennatype are popular consumed cooked meat products at all ages, which have high economical and commercial significance. However, as the most of meat products, sausages have high levels of saturated fatty acids, cholesterol, sodium chloride and curing salts (sodium nitrate-NaNo3 and sodium nitrite-NaNo2) (Honikel 2008).

Sausage is a food that is prepared from comminuted and seasoned meat, and is usually formed into a symmetrical shape. The word sausage is derived from the Latin salsus, which means salted or literally meat preserved by salting. The typical flavors, 
textures, and shapes of many sausages described today as frankfurters, braunschweiger, pork sausage, and salami were produced (Kramlich, 1974).

Thus, the consumption of sausages is not recommended in a daily intake diet because they are considered a potential health hazard that somehow is associated to be a predisposing factor for cardiovascular diseases, colon cancer, obesity and diabetes mellitus (Nisa et al., 2017).

During storage, quality attributes of the product deteriorate due to lipid oxidation and microbial growth. Lipids oxidation is responsible for reduction in nutritional quality as well as changes in flavor (Aguirreźabal et al., 2000), while microbial contamination can precipitate major public health hazards and economic loss in terms of food poisoning and meat spoilage. Thus, the application of suitable agents and possessing showed that steps both antioxidant and antimicrobial activities may be useful for maintaining meat quality, extending shelf-life and preventing economic loss (Yin and Cheng, 2003).

This work aim to evaluate the effect of different concentrations of grape seeds as powders on chemical, physical, and organoleptic properties of fresh, cooked sausages and during frozen storage at $-18^{\circ} \mathrm{C}$ for 3 months.

\section{MATERIALS AND METHODS}

\section{Materials}

\section{Source of grape seeds:}

Grape seeds (Vitis vinifera, L.) were obtained from the Ganaklez Company, Alexandria Governorate, Egypt.

BHT was purchased from El-Gomhoria Company, for Chemical, Drugs and Medical Instruments Cairo, Egypt.

\section{Source of meat and natural mutton casings:}

Meat and natural mutton casings were obtained from the local market, Cairo City, Cairo Governorate, Egypt. 
Methods:

\section{Preparation of grape seed}

The grape seeds were washed with distilled water and cleaned then dried at $50^{\circ} \mathrm{C}$ for 12 hours or until the moisture content reached the lowest amount of $2.5 \%$ to prevent water interfering. Samples were dried at $45^{\circ} \mathrm{C}$ for $24 \mathrm{hr}$. then ground to 850 mesh and kept in a closed container. Grape seeds as powder were added to the sausages by different levels (100, 300 and 600 $\mathrm{mg} / \mathrm{kg})$, while, BHT (100 $\mathrm{mg} / \mathrm{kg})$ was added as synthetic antioxidant.

\section{Preparation of natural mutton casings:}

Large intestines were removed carefully from the slaughtered animal without punctures to avoid contamination of the carcass as well as to insure not less than minimum possible length. Three essential operations were performed prior to curing: fat and mesentery were removed as completely as possible, the intestinal contents were slipped out under a spray of water to keep the exterior clean, then slimes were removed by crushing intestines manually between two successive rollers. Next, natural casings were salt cured, and were packed in barrels with salt. Prior to use, casings were soaked and washed well with water. The casings were kept wet at all times once the salt was removed prior to filling according to the method described by El-Deep (1987).

\section{Preparation of sausage:}

Sausages were prepared using the following formula according to to the method described by El-Deeb (1987) as follows: minced lean meat (beef) $66.0 \%$, fat tissues $15.47 \%$, salt (sodium chloride) $2.225 \%$, water (as ice) $15.00 \%$, species mixture $0.80 \%$, (coriander $34.06 \%$, nutmeg $2.19 \%$, clove $5.41 \%$, mace, $4.27 \%$, curcuma $1.10 \%$, black pepper $18.27 \%$, cubeb $3.84 \%$, ginger $2.19 \%$, canella $11.78 \%$, red pepper 14.70,cardamom 2.19\%), sodium alginate $0.50 \%$ and sodium nitrite $0.005 \%$. Imported frozen beef was thawed at room 
temperature and minced. The ingredients were mixed and emulsified using laboratory emulsifier (Hobart kneading machine Model C. 100 speed No. 2 (a laboratory cutter) for sausages for 810 minutes. Then the emulsion was stuffed by hand into natural mutton casings (specially prepared sheep casings, diameter 80 $\mathrm{mm})$. Different levels of grape seeds $(100,300$ and $600 \mathrm{mg} / \mathrm{kg}$ ) and BHT $(100 \mathrm{mg} / \mathrm{kg})$ as synthetic antioxidants were added to the sausages. Sausage in mutton casings was stored at $-18{ }^{\circ} \mathrm{C}$ for 3 months. Spoilage was detected by the development of off odors.

\section{Analytical methods:}

Moisture, Protein (N x 6.25 kjeldahl method), fat (hexane solvent, Soxhielt apparatus), fiber and ash were determined according to the method recommended by AOAC (2010).

\section{Carbohydrates and energy value:}

Carbohydrate calculated by differences as follows:

$\%$ Carbohydrates $=100-(\%$ moisture $+\%$ protein $+\%$ fat $+\%$ ash $+\%$ fiber $)$.

Energy value was estimated by the sum of multiplying protein and carbohydrates by 4.0 and fat by 9.0 according to FAO (1982).

\section{Determination of thiobarbituric acid value (TBA)}

TBA value was determined as described by Pearson (1970) which could be summarized as follows: Ten grams sample was distilled (distilled water $+4 \mathrm{~N} \mathrm{Hcl}$ ) for 10 minutes, $5 \mathrm{ml}$. of the distillate was added to $5 \mathrm{ml}$. T. B. A. solution $(0.28839 \mathrm{~g} \mathrm{~T}$. B. A. / $100 \mathrm{ml}$ of $90 \%$ glacial acetic acid) into a stopper tube, which was then heated in boiling water for 35 minutes. After cooling measurements were carried out colorimetrically at $538 \mathrm{~nm}$., the T.B.A. value was calculated by multiplying the absorbency by the factor (7.8) and the results were presented as grams of malonic / kg sample. 
Physical analysis:

Water holding capacity (WHC) and plasticity of the sausages samples:

Water holding capacity of sausage samples was measured as follows: an amount of sample (about $0.3 \mathrm{~g}$ ) was put under an ashless filter paper (Whatman, No.4) and pressed for $10 \mathrm{~min}$. using $1 \mathrm{~kg}$ weight. Two zones were usually obtained and measured using a planimeter. The internal zone measured indicated the plasticity, while the water holding capacity was calculated by subtracting the area of the internal zone from that of the outer (total) zone, as described by Soloviev (1966).

\section{Cooking loss:}

Sausages were weighted before and after cooking by frying in sunflower oil for $5 \mathrm{~min}$. at $110{ }^{\circ} \mathrm{C}$, then cooking loss calculated as percent of original weight as follows:

Fresh sample weight - fried sample weight

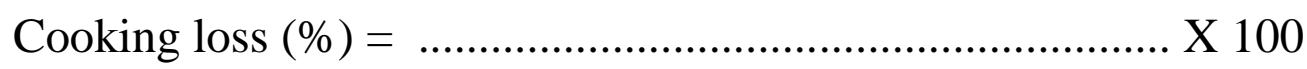

Fresh sample weight

\section{Organoleptic evaluation of sausages:}

After cooking, sausages were subjected to organoleptic tests by ten judges according to Watts et al., (1989). Jading scale for color, aroma, taste, texture and overall acceptability was as follows: very good $8-9$, good $6-7$, fair $4-5$, poor $2-3$ and very poor $0-1$.

\section{Statistical analysis:}

Analysis of variance was conducted for the data in accordance with procedures described by Steel and Torrie (1980) at $5 \%$ level of significance was used to compare between means. 


\section{RESULTS AND DISCUSSION}

\section{Chemical composition of different types of fresh sausages}

Data tabulated in Table (1) show chemical composition of fresh sausage as influenced by addition of different levels of grape seeds (on wet weight basis). It is clear to notice that control sausage (without grape seeds) recorded the highest moisture, protein and fiber content (\%), the values were $61.44 \%, 14.75 \%$ and $0.27 \%$, respectively. Sausage with BHT recorded the highest ash content and lowest carbohydrates contents. The values were $2.05 \%$ and $2.65 \%$, respectively. On the other hand, increasing grape seeds levels to the sausages showing the highest moisture, ash and fiber contents. The values were $61.50 \%$ and $1.81 \%$ and $0.05 \%$, respectively. These results are in agreement with Hai $\boldsymbol{e t}$ al., (2013).

Chemical composition of sausages as influenced by addition of different concentrations of grape seeds during frozen storage at $-18{ }^{\circ} \mathrm{C}$ for 3 months

Data presented in Table (2) showed the chemical composition of fresh sausages as influenced by addition of different levels of grape seeds during frozen storage at $-18{ }^{\circ} \mathrm{C}$ for 3 months. It is obvious that the highest moisture and protein contents and lowest energy value were recorded for control sausages. The values were $58.11,13.95 \%$ and $256.40 \mathrm{kcal} / 100 \mathrm{~g}$, respectively. With increasing grape seeds levels up to $600 \mathrm{mg} / \mathrm{kg}$ in sausages recorded the highest fat, ash, fiber and carbohydrates content. The values were $23.74,2.07,0.19$, and $4.75 \%$.These results are in agreement with that of Osama, (2001). As conclusion, the obtained data from Tables (1-2) showed that with increasing of storage period, the moisture and protein content decreased, while fat, ash, fiber, carbohydrates and energy value, increased.

Data given in Table (3) showed the changes in thiobarbituric acid value (TBA) of sausages as influenced by 
addition of different concentrations of grape seeds during storage period at $-18{ }^{\circ} \mathrm{C}$ for 3 months. It is clear to mention that at zero time (0) of storage period at $-18{ }^{\circ} \mathrm{C}$ the values of TBA were 0.30 $\mathrm{mg} / \mathrm{kg}$ for control sausage. With increasing of storage period (3 months) the values of all tested sausages increased. The values were $0.50,0.40,0.43,0.38$ and $0.34 \mathrm{mg} / \mathrm{kg}$, for control sausage, sausage with BHT, sausage with 100,300 and $600 \mathrm{mg} / \mathrm{kg}$ grape seeds, respectively. At the end of frozen storage 3 months at -18 ${ }^{\circ} \mathrm{C}$ the TBA recorded the highest values with all treated sausage samples by different rates. The values were $0.83,1.03,0.48,0.52$ and $0.45 \mathrm{mg} / \mathrm{kg}$ for the same mentioned tested sausage respectively. As conclusion, it could be concluded that the sausage with $600 \mathrm{mg} / \mathrm{kg}$ grape seeds recorded the lowest T.B.A. value due to higher antioxidant activity of grape seeds during frozen storage period. This agrees with the report of Branen, (1975) who reported that the BHA could reduce lipid oxidation in fatty foods. Also, Banon et al., (2007) mentioned that grape-fruit seed extracts have better potential as a shelf life extending antioxidant in cooked meat systems.

Physical properties of sausages as influenced by addition of different concentrations of grape seeds during frozen storage at $-18{ }^{\circ} \mathrm{C}$ for 3 months

Data presented in Table (4) show the physical properties of sausages as influenced by addition of different levels of grape seeds during frozen storage at $-18{ }^{\circ} \mathrm{C}$ for 3 months. The obtained results showed that the value of water holding capacity (WHC) at zero time (0) of storage period was $3.0 \mathrm{~cm}^{2}$. With progress of storage period for 1 months, the values of WHC decreased by different rates. The values were 2.95, 3.01, 3.00, 3.03 and 3.05 $\mathrm{cm}^{2}$, respectively for control sausage, sausage with BHT, sausage with 100,300 and $600 \mathrm{mg} / \mathrm{kg}$ grape seeds after 1 months of frozen storage, while the lowest W.H.C. values recorded at the end of storage period ( 3 months). The values were $2.73,2.72$, $2.74,2.74$ and $2.77 \mathrm{~cm}^{2}$, respectively for the same mentioned tested sausages. These changes may be due to moisture loss 
(dryness) by thawing. In case of plasticity in table (4), a strongly decrease was observed during storage of sausages with grape seeds, and it recorded the maximum decrease at the end of storage period (3 months). The plasticity decreased from 4.22 to 3.04, 4.22 to $3.05,4.22$ to $3.06,4.22$ to 3.07 and 4.22 to $2.05 \mathrm{~cm}^{2}$, respectively for control sausage, sausage with BHT, sausage with 100,300 and $600 \mathrm{mg} / \mathrm{kg}$ grape seeds after 6 months of frozen storage period, possibly due to dryness, besides protein denaturation. These results are in agreement with El-Kholie, (1994).

The values of cooking loss and yield of sausage with different levels of grape seeds are shown in Table (5). The values were $25.40 \%$ and $74.60 \%$, respectively for control sausage. With progress of storage period for 1 month a marked increase in cooking loss and decrease in yield was observed. The values were $28.60 \& 71.40 \%, 28.45 \& 71.49 \%$, and $28.36 \& 71.64 \%, 28.28 \&$ $71.72 \%$, and $28.06 \& 70.94 \%$, respectively for control sausage, sausage with BHT, sausage with 100,300 and $600 \mathrm{mg} / \mathrm{kg}$ grape seeds. The highest increase in cooking loss and decrease in yield was recorded at the end of storage period ( 3 months). The values were $33.65 \& 66.35,33.60 \& 66.35 \%, 33.2066 .80 \%, 32.90 \&$ $67.10 \%$ and $32.76 \& 67.24 \%$, respectively for the same mentioned tested sausages. Similar results were obtained by Alloush (2002). Finally, it could be concluded that addition of different concentration of grape seeds to sausages formula enhancement of all physical properties with different rates.

Organoleptic properties of sausages as influenced by addition of grape seeds $(600 \mathrm{mg} / \mathrm{kg})$ during frozen storage at $18^{\circ} \mathrm{C}$ for 3 months

The organoleptic properties of fried sausage as influenced by addition of different concentrations of grape seeds during frozen storage at $-18^{\circ} \mathrm{C}$ for 3 months are shown in Table (6). It is clear to notice that at zero time $(0)$ of frozen storage at $-18{ }^{\circ} \mathrm{C}$ all organoleptic properties (color, flavor, taste, texture and overall acceptability) recorded the highest organoleptic score (9) of the 
judging scale. While at the end of storage period (6 months) a markedly reduction in all organoleptic properties was observed. The scores ranged from (7.1 to 7.4) for color, (7.3 to 7.5) for flavor, (7.2 to 7.4) for taste, (7.0 to 7.2) for texture and (7.1 to 7.4) for overall acceptability. The obtained data are agreement with those of Badei et al., (1991). Finally, it could be concluded the sausages with grape seeds were slight better quality than that prepared with control sausage considering the organoleptic properties.

Table (1): Chemical composition of fresh sausage as influenced by addition of different concentrations of grape seeds

\begin{tabular}{|c|c|c|c|c|c|c|c|}
\hline Constituents & $\begin{array}{c}\text { Moisture } \\
\%\end{array}$ & $\begin{array}{c}\text { Protein } \\
\%\end{array}$ & $\begin{array}{c}\text { Fat } \\
\%\end{array}$ & $\begin{array}{c}\text { Ash } \\
\%\end{array}$ & $\begin{array}{c}\text { Fiber } \\
\%\end{array}$ & $\begin{array}{c}\text { Carbohy- } \\
\text { drates \% }\end{array}$ & $\begin{array}{c}\text { Energy } \\
\text { Value } \\
\text { Kcal/100g }\end{array}$ \\
\hline Sausage (control) & 61.44 & 14.75 & 18.29 & 1.87 & 0.27 & 3.38 & 237.13 \\
Sausage + BHT (100 $\mathbf{m g} / \mathrm{kg})$ & 61.45 & 14.51 & 19.31 & 2.05 & 0.03 & 2.65 & 241.77 \\
Sausage + grape seeds $(\mathbf{2 0 0} \mathrm{mg} / \mathrm{kg})$ & 61.49 & 14.52 & 19.36 & 1.51 & 0.03 & 3.09 & 243.27 \\
Sausage + grape seeds (400 $\mathrm{mg} / \mathrm{kg})$ & 61.49 & 14.35 & 19.30 & 1.81 & 0.04 & 3.01 & 243.27 \\
Sausage + grape seeds (600 $\mathbf{m g} / \mathbf{k g})$ & 61.50 & 14.30 & 19.32 & 1.81 & 0.05 & 3.02 & 243.15 \\
\hline
\end{tabular}

Table (2): Chemical composition of frozen at $-18^{\circ} \mathrm{C}$ for 3 months on sausage as influenced by addition of different concentrations of grape seeds (on wet weight basis)

\begin{tabular}{|c|c|c|c|c|c|c|c|}
\hline Constituents & $\begin{array}{c}\text { Moisture } \\
\%\end{array}$ & $\begin{array}{c}\text { Protein } \\
\%\end{array}$ & $\begin{array}{c}\text { Fat } \\
\%\end{array}$ & $\begin{array}{c}\text { Ash } \\
\%\end{array}$ & $\begin{array}{c}\text { Fiber } \\
\%\end{array}$ & $\begin{array}{c}\text { Carbohy- } \\
\text { drates \% }\end{array}$ & $\begin{array}{c}\text { Energy } \\
\text { value } \\
\text { Kcal/100g }\end{array}$ \\
\hline Sausage (control) & 58.11 & 13.95 & 21.66 & 1.99 & 0.31 & 3.98 & 256.40 \\
Sausage + BHT (100 $\mathbf{m g} / \mathbf{k g})$ & 57.31 & 13.31 & 23.06 & 2.27 & 0.12 & 3.93 & 275.24 \\
Sausage + grape seeds (200 $\mathbf{m g} / \mathbf{k g})$ & 57.05 & 13.43 & 23.21 & 1.96 & 0.14 & 4.21 & 278.19 \\
Sausage + grape seeds (400 $\mathbf{m g} / \mathbf{k g})$ & 56.34 & 13.14 & 23.60 & 2.00 & 0.18 & 4.74 & 282.66 \\
Sausage + grape seeds (600 $\mathbf{m g} / \mathbf{k g})$ & 56.46 & 12.80 & 23.74 & 2.06 & 0.19 & 4.75 & 282.60 \\
\hline
\end{tabular}


Table (3): Changes in thiobarbituric acid value (TBA) of sausages as influenced by addition of different levels of grape seeds during frozen storage at-

$18^{\circ} \mathrm{C}$ for 3 months (mg $\left./ \mathrm{Kg}\right)$

\begin{tabular}{|c|c|c|c|c|c|}
\hline $\begin{array}{l}\text { Sausage } \\
\text { Blends } \\
\text { Storage } \\
\text { period(month) }\end{array}$ & $\begin{array}{l}\text { Sausage } \\
\text { (control) }\end{array}$ & $\begin{array}{c}\text { Sausage } \\
+ \\
\text { BHT } \\
(100 \\
\mathbf{m g} / \mathbf{k g})\end{array}$ & $\begin{array}{c}\text { Sausage } \\
+ \\
\text { grape } \\
\text { peels } \\
(200 \\
\mathbf{m g} / \mathbf{k g}) \\
\end{array}$ & $\begin{array}{c}\text { Sausage } \\
+ \\
\text { grape } \\
\text { peels } \\
(400 \\
\mathrm{mg} / \mathrm{kg}) \\
\end{array}$ & $\begin{array}{c}\text { Sausage } \\
+ \\
\text { grape } \\
\text { peels } \\
(600 \\
\mathrm{mg} / \mathbf{k g}) \\
\end{array}$ \\
\hline Zero time (0) & 0.30 & 0.30 & 0.30 & 0.30 & 0.30 \\
\hline 1 & 0.50 & 0.40 & 0.43 & 0.38 & 0.34 \\
\hline 2 & 0.67 & 0.49 & 0.52 & 0.46 & 0.39 \\
\hline 3 & 0.83 & 1.03 & 0.48 & 0.50 & 0.45 \\
\hline
\end{tabular}

Table (4): Physical properties of sausages as influenced by addition of different concentrations of grape seeds during frozen storage at $-18^{\circ} \mathrm{C}$ for 3 months

\begin{tabular}{|c|c|c|c|c|c|c|c|c|c|c|}
\hline Items & \multicolumn{5}{|c|}{ Water holding capacity (WHC, $\mathrm{cm}^{2}$ ) } & \multicolumn{5}{|c|}{ Plasticity $\left(\mathrm{cm}^{2}\right)$} \\
\hline $\begin{array}{l}\text { Storage } \\
\text { period } \\
\text { (month) }\end{array}$ & Control & $\begin{array}{c}\text { BHA } \\
100 \\
\mathrm{mg} / \mathrm{kg}\end{array}$ & $\begin{array}{c}\mathrm{GS} \\
200 \\
\mathrm{mg} / \mathrm{kg}\end{array}$ & $\begin{array}{c}\mathrm{GS} \\
400 \\
\mathrm{mg} / \mathrm{kg}\end{array}$ & $\begin{array}{c}\mathrm{GS} \\
600 \\
\mathrm{mg} / \mathrm{kg}\end{array}$ & Control & $\begin{array}{c}\mathrm{BHA} \\
100 \\
\mathrm{mg} / \mathrm{kg}\end{array}$ & $\begin{array}{c}\mathrm{GS} \\
200 \\
\mathrm{mg} / \mathrm{kg}\end{array}$ & $\begin{array}{c}\mathrm{GS} \\
400 \\
\mathrm{mg} / \mathrm{kg}\end{array}$ & $\begin{array}{c}\mathrm{GS} \\
600 \\
\mathrm{mg} / \mathrm{kg}\end{array}$ \\
\hline Zero time & $3.00^{3}$ & $3.00^{3}$ & $3.00^{\mathrm{a}}$ & $3.00^{\mathrm{a}}$ & $3.00^{3}$ & $4.22^{\circ}$ & $4.22^{\mathrm{a}}$ & $4.22^{\mathrm{a}}$ & $4.22^{a}$ & $4.22^{\mathrm{s}}$ \\
\hline 1 & $2.95^{\mathrm{a}}$ & $3.00^{\circ}$ & $3.00^{\mathrm{a}}$ & $3.03^{\mathrm{a}}$ & $3.05^{\mathrm{a}}$ & $3.60^{\mathrm{b}}$ & $3.60^{b}$ & $3.62^{b}$ & $3.63^{b}$ & $3.65^{b}$ \\
\hline 2 & $2.9^{\mathrm{a}}$ & $2.90^{\mathrm{a}}$ & $3.03^{\mathrm{a}}$ & $3.05^{\mathrm{a}}$ & $3.07^{a}$ & $3.49^{b}$ & $3.48^{b}$ & $3.51^{b}$ & $3.52^{b}$ & $3.54^{b}$ \\
\hline 3 & $2.73^{\mathrm{b}}$ & $2.72^{\mathrm{b}}$ & $2.74^{\mathrm{b}}$ & $2.74^{b}$ & $2.77^{\mathrm{b}}$ & $3.04^{5}$ & $3.05^{\mathrm{c}}$ & $3.06^{\mathrm{c}}$ & $3.07^{\mathrm{c}}$ & $3.09^{\mathrm{c}}$ \\
\hline
\end{tabular}

GS $=$ Grape seeds.

Mean under the same line bearing different superscript letters are different significantly $(p \leq 0.05)$.

Table (5): Physical properties of sausages as influenced by addition of different concentrations of grape seeds during frozen storage at $-18^{\circ} \mathrm{C}$ for 3 months

\begin{tabular}{|c|c|c|c|c|c|c|c|c|c|c|}
\hline Items & & & king loss & & & & & Yield (\%) & & \\
\hline $\begin{array}{l}\text { Storage } \\
\text { period } \\
\text { (month) }\end{array}$ & Control & $\begin{array}{c}\mathrm{BHA} \\
100 \\
\mathrm{mg} / \mathrm{kg}\end{array}$ & $\begin{array}{c}\mathrm{GS} \\
200 \\
\mathrm{mg} / \mathrm{kg}\end{array}$ & $\begin{array}{c}\mathrm{GS} \\
400 \\
\mathrm{mg} / \mathrm{kg}\end{array}$ & $\begin{array}{c}\mathrm{GS} \\
600 \\
\mathrm{mg} / \mathrm{kg}\end{array}$ & Control & $\begin{array}{c}\mathrm{BHA} \\
100 \\
\mathrm{mg} / \mathrm{kg}\end{array}$ & $\begin{array}{c}\mathrm{GS} \\
200 \\
\mathrm{mg} / \mathrm{kg}\end{array}$ & $\begin{array}{c}\mathrm{GS} \\
400 \\
\mathrm{mg} / \mathrm{kg}\end{array}$ & $\begin{array}{c}\mathrm{GS} \\
600 \\
\mathrm{mg} / \mathrm{kg}\end{array}$ \\
\hline $\begin{array}{c}\text { Zero time } \\
1 \\
2 \\
3\end{array}$ & $\begin{array}{l}25.40^{\mathrm{d}} \\
28.60^{\mathrm{c}} \\
30.10^{\mathrm{b}} \\
33.65^{\mathrm{a}}\end{array}$ & $\begin{array}{l}25.30^{\mathrm{c}} \\
28.45^{\mathrm{b}} \\
29.90^{\mathrm{b}} \\
33.60^{\mathrm{a}}\end{array}$ & $\begin{array}{l}25.29^{\mathrm{c}} \\
28.36^{\mathrm{b}} \\
29.51^{\mathrm{b}} \\
33.20^{\mathrm{a}}\end{array}$ & $\begin{array}{l}25.27^{\mathrm{c}} \\
28.28^{\mathrm{b}} \\
29.20^{\mathrm{b}} \\
32.90^{\mathrm{a}}\end{array}$ & $\begin{array}{l}25.25^{\mathrm{a}} \\
28.06^{\mathrm{b}} \\
29.02^{\mathrm{b}} \\
32.76^{\mathrm{a}}\end{array}$ & $\begin{array}{l}74.60^{\mathrm{b}} \\
71.40^{\mathrm{b}} \\
69.90^{\mathrm{b}} \\
66.35^{\mathrm{t}}\end{array}$ & $\begin{array}{l}74.60^{\mathrm{a}} \\
71.45^{\mathrm{b}} \\
70.00^{\mathrm{b}} \\
66.35^{\mathrm{c}}\end{array}$ & $\begin{array}{l}74.71^{\mathrm{b}} \\
71.64^{\mathrm{b}} \\
70.49^{\mathrm{b}} \\
66.80^{\mathrm{c}}\end{array}$ & $\begin{array}{c}74.73^{\mathrm{a}} \\
71.72^{\mathrm{b}} \\
70.98^{\mathrm{b}} \\
67.10^{\mathrm{c}}\end{array}$ & $\begin{array}{l}74.75^{\mathrm{a}} \\
70.94^{\mathrm{b}} \\
70.98^{\mathrm{b}} \\
67.24^{\mathrm{c}}\end{array}$ \\
\hline
\end{tabular}

GS = Grape seeds

Mean under the same line bearing different superscript letters are different significantly $(p \leq 0.05)$. 
Table (6): Organoleptic properties of fried sausages as influenced by addition of different concentrations of grape seeds

\begin{tabular}{|c|c|c|c|c|c|c|c|c|c|c|c|c|c|c|c|}
\hline Items & \multicolumn{5}{|c|}{ Color } & \multicolumn{5}{|c|}{ Flavor } & \multicolumn{5}{|c|}{ Taste } \\
\hline $\begin{array}{l}\text { Storage } \\
\text { period } \\
\text { month }\end{array}$ & Control & $\begin{array}{c}\mathrm{BHA} \\
100 \\
\mathrm{mg} / \mathrm{kg}\end{array}$ & $\begin{array}{c}\mathrm{GS} \\
200 \\
\mathrm{mg} / \mathrm{kg}\end{array}$ & $\begin{array}{c}\mathrm{GS} \\
400 \\
\mathrm{mg} / \mathrm{kg}\end{array}$ & $\begin{array}{c}\mathrm{GS} \\
600 \\
\mathrm{mg} / \mathrm{kg}\end{array}$ & Cont & $\begin{array}{c}\mathrm{BHA} \\
100 \\
\mathrm{mg} / \mathrm{kg}\end{array}$ & $\begin{array}{c}\mathrm{GS} \\
200 \\
\mathrm{mg} / \mathrm{kg}\end{array}$ & $\begin{array}{c}\mathrm{GS} \\
400 \\
\mathrm{mg} / \mathrm{kg}\end{array}$ & $\begin{array}{c}\mathrm{GS} \\
600 \\
\mathrm{mg} / \mathrm{kg}\end{array}$ & Cont & $\begin{array}{c}\mathrm{BHA} \\
100 \\
\mathrm{mg} / \mathrm{kg}\end{array}$ & $\begin{array}{c}\mathrm{GS} \\
200 \\
\mathrm{mg} / \mathrm{kg}\end{array}$ & $\begin{array}{c}\mathrm{GS} \\
400 \\
\mathrm{mg} / \mathrm{kg}\end{array}$ & $\begin{array}{c}\mathrm{GS} \\
600 \\
\mathrm{mg} / \mathrm{kg}\end{array}$ \\
\hline 0 & $9.0^{a}$ & $9.0^{\mathrm{a}}$ & $9.0^{\mathrm{a}}$ & $9.0^{\mathrm{a}}=$ & $9.0^{\mathrm{a}}$ & $9.0^{\mathrm{a}}$ & $9.0^{\mathrm{a}}$ & $9.0^{\mathrm{a}}$ & $9.0^{\mathrm{a}}$ & $9.0^{a}$ & $9.0^{\mathrm{a}}$ & $9.0^{\mathrm{a}}$ & $9.0^{\mathrm{a}}$ & $9.0^{a}$ & $9.0^{\mathrm{a}}$ \\
\hline 1 & $8.7^{\mathrm{a}}$ & $8.8^{\mathrm{a}}$ & $8.7^{\mathrm{a}}$ & $8.8^{a}$ & $8.9^{\mathrm{a}}$ & $8.6^{\mathrm{a}}$ & $8.7^{\mathrm{a}}$ & $8.6^{\mathrm{a}}$ & $8.7^{\mathrm{a}}$ & $8.7^{\mathrm{a}}$ & $8.7^{a}$ & $8.8^{\mathrm{a}}$ & $8.7^{\mathrm{a}}$ & $8.7^{\mathrm{a}}$ & $8.8^{\mathrm{a}}$ \\
\hline 2 & $8.5^{\mathrm{ab}}$ & $8.6^{\mathrm{a}}$ & $8.5^{\mathrm{a}}$ & $8.6^{\mathrm{a}}$ & $8.6^{\mathrm{a}}$ & $8.4^{\mathrm{ab}}$ & 8.5 & 8.4 & $8.5^{\text {ab }}$ & $8.5^{\mathrm{ab}}$ & $8.5^{\mathrm{ab}}$ & $8.6^{\mathrm{a}}$ & $8.5^{\mathrm{ab}}$ & $8.6^{\mathrm{ab}}$ & $8.6^{\mathrm{a}}$ \\
\hline 3 & $8.2^{b}$ & $8.3^{b}$ & $8.1^{b}$ & $8.1^{b}$ & $8.3^{b}$ & $8.0^{6}$ & $8.1^{b}$ & $8.0^{b}$ & $8.1^{b}$ & $8.2^{b}$ & $8.3^{\mathrm{b}}$ & $8.4^{b}$ & $8.2^{b}$ & $8.2^{b}$ & $8.2^{b}$ \\
\hline
\end{tabular}

Mean under the same line bearing different superscript letters are different significantly $(\mathrm{p} \leq 0.05)$.

Continued Table (6):

\begin{tabular}{|c|c|c|c|c|c|c|c|c|c|c|}
\hline Items & \multicolumn{5}{|c|}{ Texture } & \multicolumn{5}{|c|}{ Overal acceptability } \\
\hline $\begin{array}{l}\text { Storage } \\
\text { period } \\
\text { month }\end{array}$ & Cont. & $\begin{array}{c}\text { BHA } \\
100 \\
\mathrm{mg} / \mathrm{kg}\end{array}$ & $\begin{array}{c}\mathrm{GS} \\
200 \\
\mathrm{mg} / \mathrm{kg}\end{array}$ & $\begin{array}{c}\mathrm{GS} \\
400 \\
\mathrm{mg} / \mathrm{kg}\end{array}$ & $\begin{array}{c}\mathrm{GS} \\
600 \\
\mathrm{mg} / \mathrm{kg}\end{array}$ & Cont. & $\begin{array}{c}\mathrm{BHA} \\
100 \\
\mathrm{mg} / \mathrm{kg}\end{array}$ & $\begin{array}{c}\text { GS } \\
200 \\
\mathrm{mg} / \mathrm{kg}\end{array}$ & $\begin{array}{c}\mathrm{GS} \\
400 \\
\mathrm{mg} / \mathrm{kg}\end{array}$ & $\begin{array}{c}\mathrm{GS} \\
600 \\
\mathrm{mg} / \mathrm{kg}\end{array}$ \\
\hline 0 & $9.0^{\mathrm{a}}$ & $9.0^{2}$ & $9.0^{2}$ & $9.0^{a}$ & $9.0^{a}$ & $9.0^{2}$ & $9.0^{a}$ & $9.0^{2}$ & $9.0^{3}$ & $9.0^{4}$ \\
\hline 1 & 8.5 & $8.6^{\mathrm{a}}$ & $8.6^{\mathrm{a}}$ & $8.7^{\text {a }}$ & $8.7^{\mathrm{a}}$ & $8.6^{\mathrm{a}}$ & $8.8^{\mathrm{a}}$ & $8.7^{\mathrm{a}}$ & $8.7^{\circ}$ & $8.8^{\mathrm{a}}$ \\
\hline 2 & 8.2 & $8.4^{\text {ath }}$ & $8.3^{a b}$ & $8.4^{\text {ab }}$ & $8.5^{\mathrm{ab}}$ & $8.3^{\text {ab }}$ & $8.5^{\mathrm{ab}}$ & $8.4^{\mathrm{ab}}$ & $8.4^{\mathrm{ab}}$ & $8.5^{\text {ab }}$ \\
\hline 3 & $8.0^{b}$ & $8.2^{b}$ & $8.1^{b}$ & $8.1^{b}$ & $8.2^{b}$ & $8.0^{\mathrm{b}}$ & $8.2^{b}$ & $8.1^{b}$ & $8.1^{b}$ & $8.2^{b}$ \\
\hline
\end{tabular}

Mean under the same line bearing different superscript letters are different significantly $(p \leq 0.05)$.

\section{REFERENCES}

1. Aguirrezábal, M.; Mateo, J.;Domínguez C. andZumalacárregui, J.M. (2000): The effect of paprika, garlic and salt on rancidity in dry sausages. Meat Sci., 54: 77-81.

2. Ajila, C.M.; Naidu, K.A.; Bhat, S.G. and Prasada, R. (2007): Bioactive compounds and antioxidant potential of mango peel extract. Food Chem., 105: 982-988.

3. Alloush, S.A. (2002): Evaluation of Some Spices as Natural Preservative in Processed Meat. M.Sc. Thesis, Institute of Environmental Studies and Research, Ain Shams, Univ.

4. AOAC (2010): Official Methods of the Association of Official Analytical Chemists. $15^{\text {th }}$ Ed. AOAC 2200 Wilson Boulevard Arling, Virginia, 22201, U.S.A.

5. Badei, A.Z.; Morsi, H.H. and El-Akel, A.T.M. (1991): Evaluation of chemical, physical and antimicrobial properties of cardamom essential oil. Bull. of Fac. of Agric., Cairo Univ., 42: 199-216. 
6. Banon, S.; Diaz, P.; Rodriquez, M.; Garrido, M.D. and Price, A. (2007):Ascorbate, green tea and grape seed extracts increase the shelf life of low sulphite beef patties. J. Meat. Sci., 77(4): 626-633.

7. Baydar N G (2006): Organic acids, tocopherols and phenolic compositions of some Turkish grape cultivars. Chemistry of Natural Compounds, 42 (2): 156-159.

8. Baydar, N.G.; Zkan, G. and Yasar, S. (2007): Evaluation of the antiradical and antioxidant potential of grape extracts. Food Control, 18: 1131-1136.

9. Branen, A.L. (1975): Toxicology and biochemistry of butylated hydroxyl anisole and butylated hydroxyl toluene. J. Oil. chem. Sci., 52:59-63.

10. El-Deep, S.H. (1987): Studies on the Quality of Egyptian Sausage as Determined by Certain Chemical and Microbial Changes. Ph. D. Thesis, Fac. of Agric., Ain Shams Univ. Egypt.

11. El-Kholie, E.M. (1994): The Role of Lactic Acid Cultures in Meat Preservation. MSc. Thesis, Fac. of Agriculture, Ain Shams Univ.

12. Conde, E.; Reinoso, B.D.; Gonzlez-Munoz, M. and Andrés Moure, A. (2013): Recovery and concentration of antioxidants from industrial effluents and from processing streams of underutilized vegetal biomass. Food and Public Health, 3 (2): 69-91.

13. FAO (Food and Agriculture Organization) (1982): Food Composition Tables for the Near East, FAO, Food and Nutrition Paper, p. 26.

14. Hai, Y.; Chunjun, Q.; Xueyan, W.; Qingfeng, G.; Mangang, W.; Miao, W. and Zhijun, W. (2013): Effect of grape seed and rosemary phenolics on protein oxidation in Chinese-style sausage. Journal of Food, Agriculture and Environment 11 (2): 231-236.

15. Honikel, K.O. (2008): The use and control of nitrate and nitrite for the processing of meat products. Meat Sci., 78: 68-76.

16. Kammerer, D.; Claus, A.; Carle, R. and Schieber, A. (2004): Polyphenol screening of pomace from red and white grape varieties (Vitis vinifera, L.) by HPLC-DAD-MS/MS. Journal of agricultural and Food Chemistry 52 (14): 4360-4367.

17. Kramlich, W. E. (1974): "The Meat We Eat". Tenth Edition, page: 484, The Interstate Printers and Publishers,Inc, U.S.A.

18. Kulkarni, S.; DeSantos, F.; Kattamuri, S.; Rossi, S. and Brewer, M. (2011): Effect of grape seed extract on oxidative, color and sensory stability of a pre-cooked, frozen, re-heated beef sausage model system. Meat science 88 (1):139-144. 
19. Lai, L.S.; Chou, S.T. and Chao, W.W. (2001): Studies on the antioxidative activities of Hsian-tsao (Mesonapro cumbens Hemsl) leaf gum. J. Agric. Food Chem., 49: 963-968.

20. Lee, J.; Koo, N. and Min, D.B. (2004): Reactive oxygen species, aging and antioxidative nutraceuticals. CRFSFS 3: 21-33.

21. Mehta, N.; Ahlawat, S.S.; Sharma, D.P. and Dabur, R.S. (2015): Novel trends in development of dietary fiber rich meat products: a critical review. J. Food Sci. Technol., 52 (2): 633-647.

22. Nawaz, H.; Shi, J.; Mittal, G.S. and Kakuda, Y. (2006): Extraction of polyphenols from grape seeds and concentration by ultrafiltration. Separation and Purification Technology 48 (2):176-181.

23. Nisa, A.U.; Zahra, N.; Hina, S.; Masood, S.; Javed, A. and ManzarInam,

S.

(2017): Development of meat-based functional foods: a review. J. Appl. Biol. Biotechnol, 5 (3): 86-92.

24. Osama, E. (2001): Effect of Spices Oils on Storage Period of Meat Products. MSc. Thesis, Fac. of Home Economics, Menoufia University, ShibinElkom, Egypt.

25. Pearson, D. (1970): The Chemical Analysis of Food. National College of Food Technology, University of Readings. J. And A. Churchill.

26. Rather, S.A.; Masoodi, F.A.; Akhter, R.; Rather, J.A. and Shiekh, K.A. (2018): Advances in use of natural antioxidants as food additives for improving the oxidative stability of meat Products. Madridge Journal of Food Technology, 1 (1): 10-16.

27. Soloviev, V. E. (1966): Aging of Meat. Food Industry Pub., (in Rus.).

28. Steel, E.G. andTorrrie, J.H. (1980): Principles and Procedures of Statistics. $2^{\text {nd }}$ Edit., McGraw Hill Book Company, Inc., New York, USA.

29. Uzun, I., and Bayır, A. (2010): Distribution of wild and cultivated grapes in Turkey. Not. Sci. Biol., 2 (4): 83-87.

30. Watts, B. M.; Yamaki, G. L.;Jcffcry, L. E. and Elias, L. G. (1989): Basic Sensory Methods for Food |Evaluation. ${ }^{\text {st }}$ Ed., The International Development Research Center Pub., Ottawa, Canada.

31. Yin, M.C. and Cheng, W.S. (2003): Antioxidant and antimicrobial effects of four garlic derived organosulfur compounds in ground beef. Meat Science, 63: 23-28. 